\title{
INTANGIBLE RESOURCES, EXPORT CHANNEL AND PERFORMANCE: IS THERE ANY FIT?
}

\author{
Marta FERNÁNDEZ-OLMOS' ${ }^{1}$, Isabel DÍEZ-VIAL ${ }^{2}$ \\ ${ }^{1}$ Departament of Business Administration, University of Zaragoza, \\ Gran Via 2, 50005 Zaragoza, Spain \\ ${ }^{2}$ Departament of Business Administration, University Complutense of Madrid, \\ Campus de Somosaguas, 28223 Madrid, Spain \\ E-mails: ${ }^{1}$ maferno@unizar.es (corresponding author); ${ }^{2}$ diezvial@ccee.ucm.es \\ Received 02 January 2012; accepted 31 August 2012
}

\begin{abstract}
As the resource-based view suggests, firms choose their export channel on the basis of their internal pool of resources. Following this approach, we firstly hypothesize that firms with intangible resources will establish direct export channels to better exploit, protect and develop their firm-specific resources. Secondly, we propose that firms that establish their export channel on the basis of their internal resources outperform those firms that do not. To obtain empirical evidence we used a Heckman two-step model for the DOC Rioja wine industry. The results confirm that firms improve their export performance when jointly considering internal resources and the export channel. Also, human resources are the most relevant intangible resources in our model. This paper contributes by offering empirical evidence on the exporting channel strategies chosen by Spanish wineries. This paper makes a theoretical contribution by examining the performance consequences of following the RBV approach. Likewise, it has important practical implications for managers, who can improve their firm's export performance by assessing their internal resources before considering which export channel to choose.
\end{abstract}

Keywords: resource-based view, export channel, alignment, foreign market, human resources, wine industry.

JEL Classification: F230.

\section{Introduction}

When entering a foreign market, exporting firms must choose a distribution channel through which to export their products. This implies a choice between relying on independent intermediaries and using their own resources. This is a complex and difficult decision as it determines the extent to which they are responsible for distribution, and it has clear implications for the success of the firms in international markets (Madhok 1997; Rialp et al. 2002; Root 1994).

To help managers frosm exporting firms establish the most appropriate distribution channel, the resource-based view (RBV) provides a theoretical framework based on a 
firm's internal pool of resources (Ekeledo, Sivakumar 2004; Sharma, Erramilli 2004; He et al. 2013). This suggests that firms establish their export channel to best exploit and develop their firm-specific resources, while also protecting them from appropriation by competitors (Madhok 1997). Empirically, there is extensive literature testing this model on how firms should choose the distribution channel that firms should establish (Combs, Ketchen 1999; Meyer et al. 2009; Mutinelli, Piscitello 1998).

In particular, the influence of certain resources on the chosen export channel has been analyzed. These are mainly intangible resources such as technological resources (López Rodriguez, García Rodriguez 2005; Wilkinson, Brothers 2006), reputation and advertising (Kotabe et al. 2002; Erramilli et al. 1997), human resources (Gomez-Mejia 1988; Cavusgil, Naor 1987) and firm experience (Majocchi et al. 2005; Chen, Hsu 2010). In addition, most research has examined the relationship between certain resources and the export channel without considering the consequences of these decisions on performance (Sousa et al. 2008). It is generally assumed that firms choosing their export channel on the basis of their internal resources perform better in terms of exports.

The aim of this paper is to fill this gap by examining the implication on the performance of the firms from choosing the export channel on the basis of their pool of resources. Specifically, our aim is to answer questions such as: Which kinds of resources are most relevant when choosing the export channel? Is there any fit between a firm's resources, its export channel and its export performance? Do firms that use their internal resources outperform those that do not?

In response to these questions, this research paper firstly aims to contribute to the existing literature by taking different resources into account. In contrast with other studies that focus on specific resources to explain export channel strategies, in this study we jointly consider different resources types. We therefore compare the influence and relevance of each resource from a unified perspective, following the example of previous studies largely developed for multinationals entry modes (Li 2010) rather than for export channel strategies (Peng 2001).

Secondly, this paper makes a contribution by examining the performance consequences of following the RBV approach. We examine how choosing the export channel strategies that fit with the internal pool of resources can affect a firm's performance. This analysis provides a closer link between the internal resources explaining the export channel decision and the performance of the exporting firms. Although previous literature has found that entry mode and firm performance are significantly related $(\mathrm{Lu}$, Beamish 2001; Rambocas et al. 2015), few studies have empirically examined this relationship (Aulakh, Kotabe 1997). Previous research has tended to focus on either the factors determining the export channel strategies (Brouthers, Hennart 2007; Li 2010), or on the performance consequences of each export channel strategy (Brush 2015). There has been little consideration of the need to take resources, the export channel strategy and performance all together (Sousa et al. 2008).

Finally, this paper contributes by offering empirical evidence on the exporting channel strategies chosen by Spanish wineries, which are mostly small and medium-sized 
enterprises (SMEs). Spanish wineries have extensive experience in successful exporting, since their involvement in exports has been a key factor in the development of the industry. Their products are highly valued in many markets such as the USA, Australia, China, India, New Zealand and Japan (Aylward 2006). Moreover, the wine industry represents a significant share of agricultural exports in the European Union, with an upward trend: from 2008 to 2010 the volume of EU wine exports rose by over $22 \%$, which is why the EU has become a net exporter of agri-food products for the first time since 2006, with a $€ 6$ billion surplus (European Commission) (MAP 2011).

The increasing globalization of most industries, including agricultural ones, is forcing firms to increase their presence in international markets. Nevertheless, most firms in the European Union are SMEs (according to Eurostat 99\% of all enterprises in the EU are SMEs, providing around 90 million jobs) and they still find it difficult to increase their international presence and improve their competitiveness. SMEs face resource restraints when it comes to entering international markets, so the conclusions of this research could be useful for managers of SMEs in helping them to identify which resources are most relevant.

Following this introductory section we provide a description of the conceptual framework based on the RBV. This is followed by a description of the sample and variables, and the model to be tested, after which there is a discussion of the estimation process and results. We bring to a close our study by drawing some conclusions and offering some suggestions for future research.

\section{Theoretical framework}

Previous research in internationalization has generally acknowledged the existence of different export channel strategies, varying on the basis of the degree of control exerted by the firms and the required resources (Rialp et al. 2002). In particular, two main exporting strategies can be identified: direct exporting, where firms establish direct contact with overseas customers; and indirect exporting, where firms distribute their products in international markets through an intermediary (Peng, York 2001).

Direct exporting generally involves either representatives based in the home country who travel to foreign markets or subsidiaries located in foreign countries, so firms have almost complete control over the activities they need to carry out in foreign markets (Klein et al. 1990). Compared to indirect exporting, direct exporting generally implies higher start-up costs, such as incremental investment in fixed capital and/or high informational costs to learn about the foreign market, its customers, competitors and government, and greater risks (Klein et al. 1990). In contrast, with indirect exporting the firms have little or no control over the marketing of the product as they rely on intermediaries. These intermediaries can be agents or distributors located either at home or abroad (Peng, York 2001). Compared to direct exporting, indirect modes involve less risk and resource commitment (Johanson, Wiedersheim-Paul 1975).

According to the RBV, when firms expand abroad they must select an appropriate export channel to garner the greatest value from their resources in the export market. Firms 
must try to exploit those resources that are valuable, rare, and imperfectly imitable and for which there are no commonly available substitutes (Barney 1991). Firms need to organize their distribution channel to take full advantage of their resources and attain a competitive advantage in international markets (Barney 1997; Brouthers et al. 2008).

Most of the resource-based view literature that has analyzed the role played by different resources on the export performance of firms has focused on intangible resources, rather than on physical and financial ones (Andersen, Kheam 1998; López Rodriguez, García Rodriguez 2005). According to Grant (1996), intangible resources can be technological, reputational, human, and organizational. Intangible resources are information and knowledge-based, having a much broader range of use in international markets. They have the characteristics of a public good (Campa, Guillén 1999), so they have no limit on their use and firms have an excess capacity that they can leverage abroad (Andersen, Kheam 1998; López Rodriguez, García Rodriguez 2005). More importantly, compared to other resources, intangible ones are more valuable and difficult for competitors to imitate, so they are considered as the primary source of sustained competitive advantage for the firm in national and international markets (Agarwal, Ramaswami 1992; Hennart 1982; Kogut, Singh 1988).

Existing RBV research indicates that the resources that each firm possesses are critical components of the export channel decision. More specifically, firms with valuable intangible resources enter international markets using direct export channels (Sharma, Erramilli 2004). Direct export channels reduce the risk of resource imitation by competitors (Knott 2003), while also allowing exporting firms to improve their existing resources by accessing information and knowledge on foreign markets (Henisz 2003; Madhok 1997).

Firms that use direct export channels have greater control over their foreign operations because they avoid the use of intermediaries, so they can protect their intangible resources from imitation (Blomstermo et al. 2006). Since competitors may all use the same intermediaries, there is a risk that their valuable resources, such as their brand image, their ability to innovate and introduce new and adapted products for foreign customers and their previous experience, among others, could be dispersed in the market (Mutinelli, Piscitello 1998). Moreover, intermediaries might opportunistically try to exploit the intangible resources held by a firm. For instance, intermediaries could use the reputation of a firm's products for their own benefit, or they could behave in a way that ruins the good reputation of the firm (Bresser 1988; Bresser, Harl 1986; Nielsen 1988).

Firms that use direct export channels can also improve their stock of existing resources by accessing information and knowledge on foreign markets. Firms that establish direct export channels have access to valuable information and knowledge about foreign markets, such as the different national market regulations, alternative tastes and client preferences, distribution chains, and external management practices (Majocchi et al. 2005).

As a consequence, they can improve their resources with this information and knowledge. In theory, any firm using a direct export channel could use this information and 
knowledge of international markets for its own benefit regardless of its existing resources. However, firms that have already developed intangible resources can better exploit this information and knowledge. Each firm has its own capacity to recognize the value of information and knowledge, to assimilate these or to apply them to improve their international sales (Cohen, Levinthal 1990), and firms with existing resources can take greater advantage of them. Having resources based on knowledge similar to that to be acquired in the international markets improves the capacity of the firm to take advantage of their direct relationships with international markets (Autio et al. 2000).

In contrast, firms that rely on intermediaries to sell their products abroad also depend on them to obtain information and knowledge from international markets. While it is possible to obtain information in this way, it would require a costly and time-consuming process of understanding what the intermediaries have learnt about the international markets (Barkema, Vermeulen 1998; Hisey, Caves 1985).

On the basis of the previous reasoning, we hypothesize that:

H1: A direct export channel is more likely to be chosen when firms possess intangible resources.

According to this hypothesis, firms possessing intangible resources would use a direct export mode when entering a new market. As discussed above, these firms can reduce the potential for value erosion while also better assimilating information and knowledge from international markets. In contrast, firms with lower levels of intangible resources are not concerned about losing them. In addition, export intermediaries can also obtain information and knowledge that can improve a firm's exports (Wu et al. 2007).

As a result, firms can improve their export performance by correctly choosing their export channel. It is the stock of internal resources that determines which export channel best fits each firm. By including this resource-export channel fit it is implicitly assumed that there is no single best performing export mode, because otherwise all the firms would always choose this channel. Instead, managers take into account their valuable resources when establishing the export channel that they expect to provide them with the best export performance.

This is consistent with previous studies that have directly tested the relationship between the export channel strategy and performance, although no conclusive results have been obtained. While some have found that direct channels are more profitable (Koh 1991; Lee, Griffith 2004), other researchers have found little or no impact for the type of channel on export performance (Aulakh, Kotabe 1997; Chetty, Hamilton 1993; Merino, Salas 2002). While these studies contribute to a better understanding of export channel performance differences, they do not take into account a firm's internal resources and how these fit with the direct and indirect export channels (Barney 1997; Combs, Ketchen 1999; Newbert 2007). A correct decision on the export channel to use should therefore improve a firm's export performance:

H2: Firms with export channels prescribed by the resource-based view should outperform those with channels not prescribed by the resource-based view. 


\section{Empirical analysis}

\subsection{The sample}

This study examines the wineries located in La Rioja, Spain. Almost all the wineries in the Qualified Designation of Origin (DOC) from La Rioja are small and medium-sized enterprises which have to cope with growing international competitiveness. There are few studies (e.g., Marino et al. 2001) that examine export channel decisions using data on the export distribution channel for the wine industry. As we mentioned earlier, wine exports play an important economic role, accounting for much of the total increase in EU agricultural exports during the period 2008-2010 (MAP 2011). Rioja is the most important Spanish wine region in international markets, with a market share of over $40 \%$ of total sales of premium wines. With a significant growth in wine sales in 2010, particularly in the export markets, the DOC Rioja wine industry provides an excellent source of information for the empirical testing of the theoretical framework.

The main sources used to create the list of wineries were the directories drawn up by the Regulatory Council of the Rioja DOC. Specifically, the population from which the sample is drawn consists of wineries that fulfil the following requisites: (1) they are exporting firms, (2) they belong to the DOC Rioja, (3) they are wine-making producers, (4) they are required to file accounting information with the authorities and (5) they are not cooperatives.

The data for this study were collected through the use of a structural survey. The survey data collection period ended in September 2010. In total, the population included 157 exporting wineries, from which 138 valid questionnaires were obtained, representing a response rate of over 88 percent. Of the DOC Rioja SMEs in our sample, $74.6 \%$ own a direct export channel.

\subsection{Measurement of the variables}

Two sets of dependent variables were used in this study to test the hypotheses: the direct channel, which identifies the export channel strategy; and performance. We define the direct channel variable as whether or not a firm chooses to use its own distribution network in most of its export markets, so this dependent variable is a binary variable and takes the value of one ("direct" category) when the firm uses a direct strategy and zero ("indirect" category) otherwise. So our export strategy variable considers the use of a proprietary distribution channel as an alternative to exporting through external agents. The second dependent variable is export performance. We use a subjective measurement of performance, as has also been used by several other authors (Brouthers et al. 2003; Brouthers, Nakos 2004). Subjective measures have been found to be highly correlated with objective performance measures in previous studies (Geringer, Hebert 1991; Glaister, Buckley 1998). We measured export channel performance on the basis of eight items that managers had to rate on a 10-point scale (1, very dissatisfied, to 10 , very satisfied). We followed the example of Brouthers and Nakos (2004) when choosing these items, which relate to: export sales growth, export level, profitability, market share, marketing, distribution, reputation, and market access. Factor analysis was performed 
on this set of items and one unique factor was confirmed ${ }^{1}$. Thus, the performance factor was composed of the sum of the scores for each item (Cronbach alpha $=.95)$.

Explanatory variables relating to a firm's internal resources are measured through: R\&D intensity, as a proxy for technological resources; advertising intensity, to measure reputational resources; education to measure human resources; and, finally, international experience to measure resources developed through a firm's past experiences in international markets.

The ratio of research and development expenditures to total sales ( $R \& D$ intensity) is used as a proxy for technological resources in many studies in the internationalization field as it captures a firm's efforts to improve its capacity to innovate in either products or processes (e.g., Davidson, McFetridge 1985; Erramilli et al. 1997; Gatignon, Anderson 1988; Tseng et al. 2007). A firm's reputation is the result of several factors, such as the past performance of the firm, its social responsibility, investors, degree of diversification, etc., but advertising is essential as it signals the characteristics of the product and firm. By advertising, firms not only make more information available in foreign markets, but also favourably shape information through different media (Fombrun, Shanley 1990; Chung, Kalnins 2001). As a result, an advertising measure is used as a proxy for reputation: the ratio of marketing-related expenses to total sales (Advertising intensity) (Erramilli et al. 1997; Gatignon, Anderson 1988; Tseng et al. 2007; Vachani 1995).

Exporting firms should hire employees with the skills, experience and intelligence to respond to this challenge, and this can be achieved by having a highly educated labour force (Hambrick, Mason 1984). Highly educated personnel have better problem-solving skills and are more able to effectively respond to a changing environment. Furthermore, educated employees are more open-minded and interested in foreign affairs (Garnier 1982). In general, the existing literature has found a positive relationship between the educational level of the manager and the degree of involvement in exporting (Axinn 1988). In keeping with Stiebale (2010), in this research paper human resource intensity is measured as the proportion of employees with at least three years of university education (Human resources).

Finally, we also measure international experience. As the firm develops its international experience it can improve its existing firm-specific resources in order to be more competitive (Haspeslagh, Jemison 1991). International experience refers to a firm's familiarity with foreign market environments (Ekeledo, Sivakumar 2004). This can be measured by analyzing different aspects, such as the number of years for which the firm has been exporting or the number of countries in which a firm operates internationally (Brouthers et al. 2008). We measure international experience using the number of years for which the firm has been exporting. Nevertheless, we have repeated the calculations with the number of countries as the variable and the results are fairly similar.

\footnotetext{
${ }^{1}$ The first factor was the only one that had an eigenvalue $>1$ (principal-component factors). Factor loadings: 0.899 (export sales growth), 0.909 (export level), (0.868) profitability, (0.881) market share, (0.861) marketing, (0.865) distribution, (0.801) reputation, and (0.864) market access.
} 
Several control variables have been included in addition to the variables relating to the resources held by each firm. The first control variable we examine is a firm's size, since a large firm size suggests that the firm can absorb the higher costs and risks involved in direct exporting to foreign markets (Agarwal, Ramaswami 1992; Campa, Guillén 1995; Osborne 1996). So the expectation is that smaller firms would prefer indirect exporting when competing in a foreign market. A firm's size is measured using the logarithm of the average storage capacity of the winery over the last three years. We use this measurement in its logarithmic form in order to correct for significant positive skew (Tabachnik, Fidell 2001). Hessels and Terjesen (2010) also use the natural log of firm size.

Another control variable is the level of implementation of information and communication technology (ICT). It is generally assumed that the Internet allows firms to exchange information with their customers, suppliers and business partners located abroad without setting up and maintaining an infrastructure, so reducing the need to use intermediaries to identify and communicate with international customers. We operationalized this variable using a dummy variable, which was given the value " 1 " when the firm had its own website and "0" if not (Dejo, Ramírez 2009).

Finally, we control for the age of the firm (firm's age). Export intermediaries may be particularly helpful for young firms that have little business experience and thus face a more risky and uncertain path to internationalization (Peng, Ilinitch 1998). In contrast, older firms that have existing market knowledge may be less likely to have a need for intermediaries. Following the example of previous studies (e.g., Bouquet et al. 2004; Delios, Henisz 2003; Majocchi et al. 2005), we measured a firm's experience using a logarithmic transformation of its number of years of experience in the wine-making sector (see Table 1).

\section{Results}

To examine how the fit between the explanatory variables, mainly relating to the RBV, and the export channel strategy affects a firm's performance, Shaver (1998) used a two-step analytical technique. For the first stage we ran a probit regression where the dependent variable was the export channel "direct channel" and the independent variables were the RBV factors plus the control variables. The results from this first regression allowed us to identify two main groups of firms: those whose export channel is aligned with RBV predictions, meaning that the model classifies them correctly; and those whose export channel is not aligned with the RBV predictions, meaning that the model cannot classify them correctly. We called the first group of firms "fit firms" and the second group "non-fit firms".

In stage two we ran an ordinary least squares (OLS) regression analysis where the dependent variable was the export performance of the firm. We included as the main explanatory variable the fit between the explanatory variables and the export channel obtained in stage one. Specifically, we created a dummy variable called "channel fit" that took the value " 1 " for those firms belonging to the fit group and the value " 0 " for those firms belonging to the non-fit group. We also included several control variables in the regression. 
Table 1. Measurement of variables

\begin{tabular}{|c|c|c|}
\hline Variable & Measurement & References \\
\hline \multicolumn{3}{|c|}{ Dependent variables } \\
\hline $\begin{array}{l}\text { Export } \\
\text { performance }\end{array}$ & $\begin{array}{l}\text { A ten-point scale ranging from } 1 \text { (very } \\
\text { dissatisfied) to } 10 \text { (very satisfied). Eight } \\
\text { performance criteria were included: export } \\
\text { sales growth, export level, profitability, } \\
\text { market share, marketing, distribution, } \\
\text { reputation, and market access. }\end{array}$ & $\begin{array}{l}\text { Brouthers et al. } 1999 \\
\text { Brouthers } 2002 \\
\text { Brouthers et al. } 2003 \\
\text { Brouthers and Nakos } 2004\end{array}$ \\
\hline Direct channel & $\begin{array}{l}1 \text { if the firm establishes its own exporting } \\
\text { network, } 0 \text { otherwise. }\end{array}$ & Hessels and Terjesen 2010 \\
\hline \multicolumn{3}{|c|}{ Explicative variables } \\
\hline Channel fit & $\begin{array}{l}1 \text { if the theoretically derived export } \\
\text { channel strategy coincides with the actual } \\
\text { export channel strategy, } 0 \text { otherwise. }\end{array}$ & Shaver 1998 \\
\hline $\mathrm{R} \& \mathrm{D}$ intensity & $\begin{array}{l}\text { Proportion of R\&D expenditures over } \\
\text { total sales. }\end{array}$ & $\begin{array}{l}\text { Davidson and McFetridge } 1985 \\
\text { Erramilli et al. } 1997 \\
\text { Gatignon and Anderson } 1988 \\
\text { Tseng et al. } 2007\end{array}$ \\
\hline $\begin{array}{l}\text { Advertising } \\
\text { intensity }\end{array}$ & $\begin{array}{l}\text { Proportion of advertising expenditures } \\
\text { over total sales. }\end{array}$ & $\begin{array}{l}\text { Vachani } 1995 \\
\text { Erramilli et al. } 1997 \\
\text { Gatignon and Anderson } 1988 \\
\text { Tseng et al. } 2007\end{array}$ \\
\hline $\begin{array}{l}\text { Human } \\
\text { resources }\end{array}$ & $\begin{array}{l}\text { Proportion of employees with university } \\
\text { degree. }\end{array}$ & Plechero and Chaminade 2010 \\
\hline $\begin{array}{l}\text { International } \\
\text { experience }\end{array}$ & $\begin{array}{l}\text { (i) The uninterrupted number of years a } \\
\text { firm has been exporting. } \\
\text { (ii) Number of foreign countries served }\end{array}$ & $\begin{array}{l}\text { Sánchez-Peinado } \\
\text { and Pla-Barber } 2006 \\
\text { Wu et al. } 2007 \\
\text { Tallman and Li } 1996 \\
\text { Zahra et al. } 2000 \\
\text { Barkema et al. } 1996\end{array}$ \\
\hline Firm's size & $\begin{array}{l}\text { The logarithm of the average storage } \\
\text { capacity of the winery. }\end{array}$ & Benjamin and Podolny 1999 \\
\hline $\begin{array}{l}\text { Information and } \\
\text { communication } \\
\text { technology }\end{array}$ & $\begin{array}{l}1 \text { if the firm has its own website, } 0 \\
\text { otherwise. }\end{array}$ & $\begin{array}{l}\text { Nieto and Fernández } 2005 \\
\text { Dejo and Ramirez } 2009\end{array}$ \\
\hline Firm's age & $\begin{array}{l}\text { The logarithm of the number of years of } \\
\text { experience in the wine industry. }\end{array}$ & $\begin{array}{l}\text { Delios and Henisz } 2003 \\
\text { Bouquet et al. } 2004 \\
\text { Majocchi et al. } 2005\end{array}$ \\
\hline
\end{tabular}


Table 2 contains the means, standard deviations, and Spearman's correlations ${ }^{2}$ for all the variables used in the study. All correlations remain below 0.6, so there is no serious risk of multi-collinearity (Schwens, Kabst 2011).

Table 2. Spearman's correlations

\begin{tabular}{|c|c|c|c|c|c|c|c|c|c|c|}
\hline & 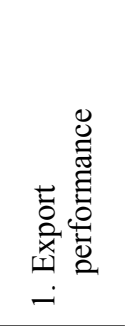 & 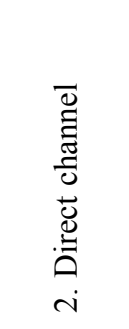 & 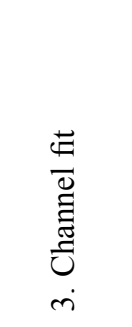 & 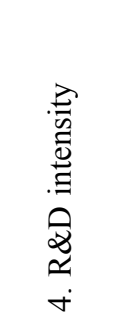 &  & 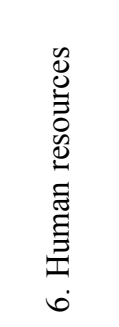 & 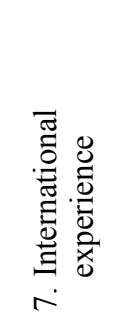 & $\begin{array}{l}\tilde{N} \\
\infty \\
\infty \\
\Xi \Xi \Xi \\
\infty \\
\infty\end{array}$ & 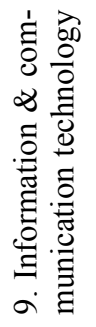 & 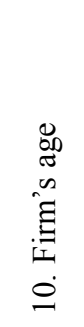 \\
\hline 1 & 1 & & & & & & & & & \\
\hline 2 & $0.252 * *$ & 1 & & & & & & & & \\
\hline 3 & $0.282 * *$ & $0.587 * *$ & 1 & & & & & & & \\
\hline 4 & $0.172 *$ & 0.161 & 0.134 & 1 & & & & & & \\
\hline 5 & $0.237 * *$ & $0.184^{*}$ & 0.108 & $0.205^{*}$ & 1 & & & & & \\
\hline 6 & 0.040 & $0.183^{*}$ & $0.244 * *$ & $0.251 * *$ & 0.090 & 1 & & & & \\
\hline 7 & 0.085 & 0.162 & 0.015 & 0.094 & 0.057 & -0.112 & 1 & & & \\
\hline 8 & 0.097 & $0.314 * *$ & $0.348^{* *}$ & 0.161 & 0.128 & -0.028 & $0.522 * *$ & 1 & & \\
\hline 9 & -0.137 & $0.280^{* *}$ & 0.018 & 0.074 & $0.247 * *$ & -0.016 & $0.198^{*}$ & $0.337 * *$ & 1 & \\
\hline 10 & 0.006 & 0.030 & -0.070 & 0.140 & 0.047 & 0.083 & $0.538 * *$ & $0.196^{*}$ & 0.111 & 1 \\
\hline Mean & 35.885 & 0.746 & 0.768 & 1.206 & 4.145 & 0.218 & 15.391 & 14.323 & 0.855 & 3.192 \\
\hline DV & 9.834 & 0.437 & 0.424 & 2.424 & 4.523 & 0.208 & 17.847 & 1.324 & 0.353 & 0.956 \\
\hline
\end{tabular}

Note: $(*),(* *)$ indicate parameter significance at the 5 and 1 per cent level, respectively.

\subsection{Export channel strategy}

Table 3 shows the marginal effects for our stage one export channel strategy probit model. The probit model was significant $(\mathrm{p}<0.0002)$ with a moderate chi-square (27.98), and it correctly classified 76.81 percent of the firms' export channel strategies. We observed as significant predictors of the export channel strategy: human resources, firm size, and information and communication technology. In particular, firms that use direct export channels have greater human resources, have a higher size, and use ICTs. Contrary to expectations, R\&D intensity, advertising intensity and international experience had no significant impact on the export channel strategy.

\footnotetext{
${ }^{2}$ The Kolmogorov-Smirnov test determined that the variables are not normally distributed, so we cannot use Pearson's correlations.
} 
Table 3. Marginal effects for binary probit models

\begin{tabular}{lcc}
\hline \multicolumn{1}{c}{ Dependent variable } & \multicolumn{2}{c}{ Export channel (direct) } \\
\hline R\&D intensity & dy/dx & Std. err. \\
\hline Advertising intensity & 0.016 & 0.018 \\
\hline Human resources & 0.006 & 0.009 \\
\hline International experience & $0.388^{* *}$ & 0.190 \\
\hline Firm's size & 0.004 & 0.004 \\
\hline Information and communication technology & $0.089^{* *}$ & 0.038 \\
\hline Firm's age & $0.242^{*}$ & 0.129 \\
\hline McFadden's Adj $\mathrm{R}^{2}$ & -0.041 & 0.043 \\
\hline Likelihood ratio test & \multicolumn{3}{c}{0.179} \\
\hline Chi-square statistic & \multicolumn{3}{c}{0.0002} \\
\hline Predicted capacity & \multicolumn{3}{c}{$138.81 \%$} \\
\hline Number of observations & \multicolumn{3}{c}{} \\
\hline
\end{tabular}

Notes: $(*),(* *)$ indicate parameter significance at the 5 and 1 per cent level, respectively. Marginal effects are computed at the sample means. Standard errors in parenthesis.

\subsection{Export performance}

Stage two of the model tries to test whether firms that choose their export channel on the basis of their internal resources, namely the "fit firms", outperform those that do not, namely the "non-fit firms". 106 firms were correctly classified in the stage one model (Table 3), meaning that the model can correctly explain their export channel.

A preliminary t-test of export performance differences between these two groups of firms was run in order to establish if there are significant differences between their export performances. The fit firm group has an average export performance score of 37.67, while the non-fit firm group has an average export performance score of 29.97. The t-test showed that export performance differences between these groups are significant $(\mathrm{t}=-4.101, \mathrm{p}<0.001)$, so hypothesis 2 is bivariately supported.

We also ran an OLS regression to test hypothesis 2 . Table 4 provides the results for the OLS regression explaining export performance by considering the channel fit, along with other variables. Channel fit is positive and significant, which implies that choosing the export channel in response to the availability of resources increases export performance. Along with channel fit we observe that the reputational resources are a significant predictor of export performance. Contrary to what is generally assumed in the literature, the "direct channel" variable is not significantly related to export performance in this model.

Along with the explanatory variables, Table 4 also includes a self-selection correction term to resolve the problem noted by Shaver (1998) for this type of study. Because the 
export channel is a strategic decision, there may be some unobserved factors influencing this strategy and ignoring this fact (i.e. that export channel decisions are endogenous) can lead to incorrect performance regression results. Heckman (1979) develops a twostep approach to resolving this endogeneity problem. This modelling re-estimates the regression coefficients by introducing a self-selection correction term $(\lambda)$ "inverse Mills ratio", into the performance model (Shaver 1998). This self-selection correction term $(\lambda)$ is significant in our model, which indicates that unobserved characteristics affect both the export channel and export performance.

Finally, as can be seen from Table 5, we employed multi-collinearity tests using variance inflation factors (VIFs). VIFs are below 10 (the highest VIF is 8.01). The results showed in Table 5 lead us to conclude that multi-collinearity is not a concern (O'Brien 2007).

Table 4. Marginal effects for OLS regression models

\begin{tabular}{lcc}
\hline \multicolumn{1}{c}{ Dependent variable } & \multicolumn{2}{c}{ Export performance } \\
\hline Direct channel & $\mathrm{dy} / \mathrm{dx}$ & Std. err. \\
\hline Channel fit & 4.156 & 2.325 \\
\hline R\&D intensity & $5.171^{*}$ & 2.455 \\
\hline Advertising intensity & 0.478 & 0.396 \\
\hline Human resources & $0.637^{* *}$ & 0.194 \\
\hline International experience & 14.858 & 7.964 \\
\hline Firm's size & 0.122 & 0.064 \\
\hline Information and communication & 3.069 & 1.639 \\
technology & 5.251 & 5.272 \\
\hline Firm's age & & 1.052 \\
\hline Self-correction $(\lambda)$ & -1.317 & \\
\hline $\mathrm{R}^{2}$ adjusted & $24.481^{*}$ & \\
\hline F-Snedecor statistic & & 11.171 \\
\hline
\end{tabular}

Notes: $(*),(* *)$ indicate parameter significance at the 5 and 1 per cent level, respectively. Standard errors in parenthesis.

Table 5. Variance inflation factors (VIF)

\begin{tabular}{lc}
\hline \multicolumn{1}{c}{ Variables } & VIF \\
\hline Direct channel & 1.75 \\
\hline Channel fit & 1.84 \\
\hline R\&D intensity & 1.56 \\
\hline Advertising intensity & 1.30 \\
\hline Human resources & 4.65 \\
\hline International experience & 2.22 \\
\hline Firm's size & 8.01 \\
\hline Information and communication technology & 5.90 \\
\hline Firm's age & 1.72 \\
\hline
\end{tabular}




\section{Discussion}

The results obtained from this research highlight the importance of human resources in explaining export channel strategies. As several studies have confirmed (e.g., Hessels, Terjesen 2010), firms lacking human resources are more likely to prefer indirect exporting. Compared to indirect export channels, direct exporting demands a large human resource commitment. Increasing involvement in foreign markets is likely to require a greater number of people inside the firm with the necessary skills for successfully managing an international growth process, such as learning about foreign markets, customs, regulations, etc. Moreover, if the firm has capable employees and managers it can more readily assimilate and exploit new information and knowledge gained from international markets (Fernhaber et al. 2009).

Contrary to expectations, R\&D intensity, advertising intensity, and international experience are not significantly related to a firm's export channel. It appears that technological and reputational resources do not affect a firm's export channel. Previous evidence has found a positive effect for R\&D expenditures, advertising investments and international experience when explaining export intensity (Burton, Schlegelmich 1987; Fraser, Hite 1990; Hirsch, Bijaoui 1985; Kumar, Siddharthan 1994), but the results are inconclusive when it comes to their effect on establishing the export channel. While some studies have found a positive effect (Kim, Daniels 1991; Rialp et al. 2002) others have found no significant effect (Kogut, Singh 1988; Merino, Salas 2002).

It was proposed in hypothesis 1 that firms with better intangible resources would establish a direct export channel to avoid imitation by competitors and to improve their resources through using information and knowledge. It seems that it is the ability of the employees and managers, rather than other resources that improve a firm's capacity to understand and assimilate information and knowledge from other markets. Moreover, wineries tend to be located in a cluster, so they can directly learn from their competitors' international strategies without relying on intermediaries. Since they are in close proximity and they undertake similar activities, they can learn from others through observing neighbouring firms, informal interactions, sharing suppliers, etc. (Shaver, Flyer 2000; Canina et al 2005). This can be clearly seen through advertising: since all the firms belong to the same DOC, advertising by one local firm improves the reputation of all the DOC's firms.

Although the traditional explanation is that firms can gain valuable knowledge and resources as they accumulate international experience, one possible explanation for the lack of significance of this variable could be that firms can develop other mechanisms to acquire the requisited knowledge and resources. One possible mechanism could be the management team's international mechanism. Reubert and Fischer (1997) showed that internationally experienced management teams have a greater propensity to develop foreign strategic partners and hence, they are associated with a higher degree of internationalization. Likewise, Korsakienè and Tvaronavičienè (2012) obtained that Norwegian SMEs perceive variables of international entrepreneurship theory as the important contributory factors in internationalization process. 
Nevertheless, the main objective of this research, to test whether the fit between intangible resources and export channel choice affects performance, has been achieved (hypothesis 2). On the one hand, the export channel strategy (direct channel) has not been found to be significant. This result indicates that export channel strategies have no significant direct effect on export performance. On the other hand, the variable channel fit is significantly related to export performance. The proposed model therefore serves to confirm that firms with human resources that establish direct export strategies perform better.

\section{Conclusions, limitations and future research}

The scholars in the field of international management are interested in describing and understanding why exporting firms differ in their export channel choices and how this affects subsequent export performance. Indeed, much of the work in the field can be categorized into studies that have explained the choice between direct and indirect export modes, and those that have examined its export performance implications. A majority of the papers in the first group estimates channel choice models rather than examining export performance directly. In contrast to the previous one, the second group of studies examines the performance implications of entry mode decisions. These studies need to address the endogeneity problem that may arise when such decisions are closely linked to unobserved attributes, and these decisions are made based on firms' performance expectations (Shaver 1998). In such situations, a two-step approach permits an integrative model that simultaneously captures firms' export channel decisions as well as the observed and unobserved determinants of these decisions and their performance implications. In order to obtain unbiased results in these settings, empirical models must correct for endogeneity (i.e., simultaneously address firms' entry mode choices as well as their drivers and consequences), which is a fundamental challenge in international management literature (Reeb et al. 2006).

The objective of this research is to understand why exporting firms differ in their export channel choices and how this choice affects subsequent export performance. Following the RBV, we have taken into account different intangible resources in order to evaluate the role that each resource type (technological, reputational, human, and organizational) plays in explaining the export channel.

It is proposed that firms with a large intangible pool of resources tend to establish direct export channels as a way of protecting these from competitors. Firms with intangible resources can also improve them by increasing their ability to interpret, understand and assimilate information and knowledge about foreign markets. As a result, we hypothesize that firms that take into account their resources in choosing the export channel should outperform those that do not take them into consideration.

The results confirm that firms choosing their export channels on the basis of their resources perform better. In contrast to previous studies that tried to directly link the export channel with export performance, in this research we find that it is the fit between intangible resources and the chosen export channel that affects export performance. In particular, the results show that human resources are the most relevant elements of the firm for aligning export channel choice and performance. 
Nevertheless, the paper also highlights some limitations which raise some possible avenues for future research. First, the lack of significance for some intangible resources requires further study. It would be interesting to use other samples to test the relevance of these resources in explaining the export channel. The role that geographical proximity among rival firms may play in these results would also be an interesting factor for analysis. Several studies have pointed out that resources can easily spread locally, so firms may fear imitation by rivals locally rather than through intermediaries (Shaver, Flyer 2000).

Korsakienė, Tvaronavičienė (2012) have obtained that Norwegian SMEs perceive variables of international entrepreneurship theory as the important contributory factors in internationalization process. Based on this argument, future research could analyze the age of the entrepreneur in order to shed light on the export behaviors of SMEs.

Secondly, we have assumed that firms can use only one export channel: direct or indirect channel, and not both. This assumption has been widely applied in previous studies and most wineries from La Rioja use just one, but in reality firms may employ different entry modes in different markets or even multiple modes in the same market. Future research may wish to examine a wider array of export channels such as sales delegation, commission local agents, independent foreign distributors, and other intermediaries. This work could be performed using different combinations of these, which may improve the explanatory power of the model.

Finally, a whole spectrum of the export development process may exist, implying a gradual replacement of indirect channels with direct export networks or vice versa (Root 1994). Studies involving dynamic processes, such as entry model strategy, may therefore require a temporal element to make longitudinal designs more appropriate (Agarwal, Ramaswami 1992), but this would require time series data that are not available in our study.

The results of this research also have important implications for managers. Increasing globalization is a great opportunity for SMEs, but they also face the problem of resource restraints. First, we have established a link between intangible resources, export channel and export performance, so managers should consider all of these together and not treat them as separate issues. Secondly, managers trying to successfully establish direct export channels should develop qualified human resources as these are critical to understanding and developing new resources to meet the demands of international markets. Finally, managers can improve their firm's export performance by assessing their internal resources before considering which export channel to choose.

\section{Acknowledgements}

This project has been supported by the ECO2009-09623 and ECO2011-29445 projects (Ministry of Science and Innovation, National R\&D Plan - Ministerio de Ciencia e Innovación, Plan Nacional de I + D + i), the CREVALOR group from University of Zaragoza and CR35/10-A UCM from Complutense University of Madrid. 


\section{References}

Agarwal, S.; Ramaswami, S. 1992. Choice of foreign entry mode: impact of ownership, location, and internalization factors, Journal of International Business Studies 23: 1-27.

http://dx.doi.org/10.1057/palgrave.jibs.8490257

Andersen, O.; Kheam, L.S. 1998. Resource-based theory and international growth strategies: an exploratory study, International Business Review 7: 163-184.

http://dx.doi.org/10.1016/S0969-5931(98)00004-3

Aulakh, P. S.; Kotabe, M. 1997. Antecedents and performance implications of channel integration in foreign markets, Journal of International Business Studies 28(1): 145-175.

http://dx.doi.org/10.1057/palgrave.jibs.8490096

Autio, E.; Sapienza, H.; Almeida, J. 2000. Effect of age at entry, knowledge intensity, and imitability on international growth, Academy of Management Journal 43: 909-24.

http://dx.doi.org/10.2307/1556419

Axinn, C. N. 1988. Export performance: do managerial perceptions make a difference?, International Marketing Review 5: 61-71. http://dx.doi.org/10.1108/eb008353

Aylward, D. K. 2006. Global pipelines: profiling successful SME exporters within the Australian wine industry, International Journal of Technology, Policy and Management 6: 49-65.

http://dx.doi.org/10.1504/IJTPM.2006.010072

Barkema, H. G.; Bell, J. H. J.; Pennings, J. M. 1996. Foreign entry, cultural barriers, and learning, Strategic Management Journal 17: 151-166.

http://dx.doi.org/10.1002/(SICI)1097-0266(199602)17:2<151::AID-SMJ799>3.0.CO;2-Z

Barkema, H. G.; Vermeulen, G. A. M. 1998. International expansion through start-up or through acquisition: an organizational learning perspective, Academy of Management Journal 41(1): 7-26. http://dx.doi.org/10.2307/256894

Barney, J. 1991. Firm resources and sustainable competitive advantage, Journal of Management 17: 99-120. http://dx.doi.org/10.1177/014920639101700108

Barney, J. B. 1997. Gaining and sustaining competitive advantage. Upper Saddle River, NJ: Pearson Education, Inc.

Benjamin, B. A.; Podolny, J. M. 1999. Status, quality, and social order in the California wine industry, Administrative Science Quarterly 44(3): 563-589. http://dx.doi.org/10.2307/2666962

Blomstermo, A.; Sallis, J.; Sharma, D. D. 2006. Choice of foreign market entry mode in service firms, International Marketing Review 23(2): 211-229. http://dx.doi.org/10.1108/02651330610660092

Bouquet, C.; Hébert, L., Delios, A. 2004. Foreign expansion in service industries: separability and human capital intensity, Journal of Business Research 57(1):35-46.

http://dx.doi.org/10.1016/S0148-2963(02)00282-5

Bresser, R. K. 1988. Matching collective and competitive strategies, Strategic Management Journal 9: 375-385. http://dx.doi.org/10.1002/smj.4250090407

Bresser, R. K.; Harl, J. E. 1986. Collective strategy: vice or virtue?, Academy of Management Review 11: 408-427. http://dx.doi.org/10.5465/AMR.1986.4283447

Brouthers, K. D. 2002. Institutional, cultural and transaction cost influences on entry mode choice and performance, Journal of International Business Studies 33(2): 203-222.

http://dx.doi.org/10.1057/palgrave.jibs.8491013

Brouthers, L. E.; Brouthers, K. D.; Werner, S. 1999. Is Dunning's eclectic framework descriptive or normative?, Journal of International Business Studies 30: 831-844.

http://dx.doi.org/10.1057/palgrave.jibs.8490842 
Brouthers, K.; Brouthers, L. E.; Werner, S. 2003. Transaction cost-enhanced entry mode choices and firm performance, Strategic Management Journal 24: 1239-1248.

http://dx.doi.org/10.1002/smj.362

Brouthers, K. D.; Brouthers, L. E.; Werner, S. 2008. Resource-based advantages in an international context, Journal of Management 34: 189-217. http://dx.doi.org/10.1177/0149206307312508

Brouthers, K. D.; Hennart, J. F. 2007. Boundaries of the firm: insights from international entry mode research, Journal of Management 33(3): 395-425. http://dx.doi.org/10.1177/0149206307300817

Brouthers, K.; Nakos, G. 2004. SME entry mode choice and performance: a transaction cost perspective, Entrepreneurship Theory and Practice 28: 229-247.

http://dx.doi.org/10.1111/j.1540-6520.2004.00041.x

Brush, C. G. 2015. export entry in small companies: effecs of timing on strategy and performance, Journal of Small Business Strategy 7(3): 53-68.

Burton, F. N.; Schlegelmilch, B. B. 1987. Profile analyses of non-exporters versus exporters grouped by export involvement, International Marketing Review 27: 38-49.

Campa, J. M.; Guillén, M. F. 1995. The internalization of exports: commercial alliances and proprietary distribution channels of Spanish firms, in $V$ Congreso Nacional de la Asociación Científica de Economía y Dirección de la Empresa, September 1995, Empresa, Madrid.

Campa, J. M.; Guillén, M. F. 1999. The internalization of exports: firm- and location-specific factors in a middle-income country, Management Science 45: 1463-78.

http://dx.doi.org/10.1287/mnsc.45.11.1463

Canina, L.; Eriz, C.; Harrison, J. 2005. Agglomeration effects and strategic orientation: evidence from the U.S. lodging industry, Academy of Management Journal 48: 565-568.

http://dx.doi.org/10.5465/AMJ.2005.17843938

Cavusgil, S. T.; Naor, J. 1987. Firm and management characteristics as discriminators of export marketing activity, Journal of Business Research 15(3): 221- 235.

http://dx.doi.org/10.1016/0148-2963(87)90025-7

Chen, H.; Hsu, C. 2010. Internationalization, resource allocation and firm performance, Industrial Marketing Management 39: 1103-1110. http://dx.doi.org/10.1016/j.indmarman.2009.10.001

Chetty, S. K.; Hamilton, R. T. 1993. Firm-level determinants of export performance: a meta-analysis, International Marketing Review 10(3): 26-34. http://dx.doi.org/10.1108/02651339310040643

Chung, W.; Kalnins, A. 2001. Agglomeration effects and performance: a test of the Texas lodging industry, Strategic Management Journal 22(10): 969-988. http://dx.doi.org/10.1002/smj.178 Cohen, W.; Levinthal, D. 1990. Absorptive capacity: a new perspective on learning and innovation, Administrative Science Quarterly 35: 128-152. http://dx.doi.org/10.2307/2393553

Combs, J.; Ketchen, D. 1999. Explaining interfirm cooperation and performance: toward a reconciliation of predictions from the resource-based view and organizational economics, Strategic Management Journal 20(9): 867-888.

http://dx.doi.org/10.1002/(SICI)1097-0266(199909)20:9<867::AID-SMJ55>3.0.CO;2-6

Davidson, W. H.; McFetridge, D. G. 1985. Key characteristics in the choice of international technology transfer, Journal of International Business Studies 16: 5-21.

http://dx.doi.org/10.1057/palgrave.jibs.8490448

Dejo, N.; Ramírez, N. 2009. Export behavior: a study of Spanish SMEs, Globalization, Competitiveness and Governability 3: 52-67.

Delios, A.; Henisz, W. 2003. Political hazards, experience, and sequential entry strategies: the international expansion of Japanese firms, 1980-1998, Strategic Management Journal 24(11): 1153-1164. http://dx.doi.org/10.1002/smj.355 
Ekeledo, I.; Sivakumar, K. 2004. International market entry mode strategies of manufacturing firms and service firms: a resource-based perspective, International Marketing Review 21: 68101. http://dx.doi.org/10.1108/02651330410522943

Erramilli, M. K.; Agarwal, S.; Kim, S. S. 1997. Are firm specific advantages location-specific too?, Journal of International Business Studies 28(4): 735-757.

http://dx.doi.org/10.1057/palgrave.jibs.8490117

Fernhaber, S. A.; McDougall-Covin, P. P.; Shepherd, D. A. 2009. International entrepreneurship: leveraging internal and external knowledge sources, Strategic Entrepreneurship Journal 3(4): 297-320. http://dx.doi.org/10.1002/sej.76

Fombrun, C. J.; Shanley, M. 1990. What's in a name? Reputation building and corporate strategy, Academy of Management Journal 33: 233-258. http://dx.doi.org/10.2307/256324

Fraser, C.; Hite, R. 1990. Impact of international marketing strategies on performance in diverse global markets, Journal of Business Research 20: 249-262.

http://dx.doi.org/10.1016/0148-2963(90)90016-7

Garnier, G. 1982. Comparative export behaviour of small Canadian firms in the printing and electrical industries, in M. R. Czinkota, G. Tesar, (Eds.). Export management: an international context. New York: Praeger Publishers.

Gatignon, H.; Anderson, E. 1988. The multinational corporation's degree of control over foreign subsidiaries: an empirical test of a transaction cost explanation, Journal of Law, Economics and Organization 4: 304-336.

Geringer, J. M.; Hebert, L. 1991. Measuring performance of international joint ventures, Journal of International Business Studies 22: 249-263. http://dx.doi.org/10.1057/palgrave.jibs.8490302

Glaister, K. W.; Buckley, P. J. 1998. Measures of performance in UK international aliiances, Organization Studies 19: 89-118. http://dx.doi.org/10.1177/017084069801900105

Gomez-Mejia, L. R. 1988. The role of human resources strategy in export performance: a longitudinal study, Strategic Management Journal 9: 493-505. http://dx.doi.org/10.1002/smj.4250090508 Grant, R. M. 1996. Toward a knowledge-based theory of the firm, Strategic Management Journal 17: 109-122. http://dx.doi.org/10.1002/smj.4250171110

Hambrick, D.; Mason, P. 1984. Upper echelons: the organization as a reflection of its top managers, Academy of Management Review 9(2): 193-206.

Haspeslagh, P. C.; Jemison, D. B. 1991. Managing acquisitions: creating value through corporate renewal. New York: Free Press.

He, X.; Brouthers, K. D.; Filatotchev, I. 2013. Resource-based and institutional perspectives on export channel selection and export performance, Journal of Management 39(1): 27-47.

http://dx.doi.org/10.1177/0149206312445926

Heckman, J. 1979. Sample selection bias as a specification error, Econometrica 47: 153-161. http://dx.doi.org/10.2307/1912352

Henisz, W. J. 2003. The power of the Buckley and Casson thesis: the ability to manage institutional idiosyncrasies, Journal of International Business Studies 34: 173-184.

Hennart, J.-F. 1982. The theory of the multinational enterprise. University of Michigan Press: Ann Arbor, MI.

Hessels, J.; Terjesen, S. 2010. Resource dependency and institutional theory perspectives on direct and indirect export choices, Small Business Economics 34: 203-220.

http://dx.doi.org/10.1007/s11187-008-9156-4

Hirsch, S.; Bijaoui, I. 1985. R\&D intensity and export performance: a micro view, Weltwirtschaftliches Archiv 121: 138-251. http://dx.doi.org/10.1007/BF02705822 
Hisey, K. G.; Caves, R. E. 1985. Diversification strategy and choice of country: diversifying acquisitions abroad by U.S. multinationals, Journal of International Business Studies 16: 51-64. http://dx.doi.org/10.1007/BF02705822

Johanson, J.; Wiedersheim-Paul, F. 1975. The internationalization of the firm: four Swedish case studies, Journal of Management Studies 12: 305-22.

http://dx.doi.org/10.1111/j.1467-6486.1975.tb00514.x

Kim, J.; Daniels, J. D. 1991. Marketing channel decisions of foreign manufacturing subsidiaries in the US: the case of the metal and machinery industries, Management International Review 31(2): 123-139.

Klein, S.; Frazier, G. L.; Roth, V. J. 1990. A transaction cost analysis model of channel integration, Journal of Marketing Research 27: 196-208. http://dx.doi.org/10.2307/3172846

Knott, A. M. 2003. Persistent heterogeneity and sustainable innovation, Strategic Management Journal 24(8): 687-705. http://dx.doi.org/10.2307/3172846

Kogut, B.; Singh, H. 1988. The effect of national culture on the choice of entry mode, Journal of International Business Studies 19: 414-432. http://dx.doi.org/10.1057/palgrave.jibs.8490394

Koh, A. C. 1991. Relationships among organizational characteristics, marketing strategy and export performance, International Marketing Review 8(3): 46-60.

http://dx.doi.org/10.1108/02651339110004906

Korsakienė, R.; Tvaronavičienė, M. 2012. The internationalization of SMEs: an integrative approach, Journal of Business and Management 13(2): 294-307.

http://dx.doi.org/10.3846/16111699.2011.620138

Kotabe, M.; Srinivasan, S. S.; Aulakh, P. S. 2002. Multinationality and firm performance: the moderating role of R\&D and marketing capabilities, Journal of International Business Studies 33: 79-97. http://dx.doi.org/10.1057/palgrave.jibs.8491006

Kumar, N.; Siddhartan, N. 1994. Technology, firm size and export behaviour in developing countries: the case of Indian enterprise, Journal of Development Studies 32(2): 288-309.

http://dx.doi.org/10.1080/00220389408422362

Lee, C.; Griffith, D. L. 2004. The marketing strategy-performance relationship in an export driven developing economy: a Korean illustration, International Marketing Review 21: 321-334.

http://dx.doi.org/10.1108/02651330410539648

Li, M. 2010. Determinants of exporting channel integration: an interaction approach, Management and Marketing 5: 19-38.

López Rodriguez, J.; García Rodriguez, R. 2005. Technology and export behaviour: a resourcebased approach, International Business Review 14: 539-557.

http://dx.doi.org/10.1016/j.ibusrev.2005.07.002

Lu, J.; Beamish, P. W. 2001. Internationalization and performance of SMEs, Strategic Management Journal 22(6/7): 565-586. http://dx.doi.org/10.1002/smj.184

Madhok, A. 1997. Cost, value and foreign market entry mode: the transaction and the firm, Strategic Management Journal 18: 39-61.

http://dx.doi.org/10.1002/(SICI)1097-0266(199701)18:1<39::AID-SMJ841>3.0.CO;2-J

Majocchi, A.; Bacchiocchi, E.; Mayhrofer, U. 2005. Firm size, business experience and export intensity in SMEs: a longitudinal approach to complex relationships, International Business Review 14: 719-738. http://dx.doi.org/10.1016/j.ibusrev.2005.07.004

MAP-Monitoring Agri-Trade Policy. 2011. Global and EU agricultural exports rebound, No 01-11, May 2011. European Commission.

Marino, K.; Castaldi, R.; Sengupta, S.; Silverman, M. 2001. Direct and indirect export channel decisions: product and firm characteristics in the U.S. wine industry, in International Applied Business Research Conference Proceedings, March 2001, Cancun, Mexico. 
Merino, F.; Salas, V. 2002. Causes and consequences of exports channel integration, Spanish Economic Review 4: 239-259. http://dx.doi.org/10.1007/s101080200056

Meyer, K. E.; Estrin, S.; Bhaumik, S. K.; Peng, M. W. 2009. Institutions, resources, and entry strategies in emerging economies, Strategic Management Journal 30(1): 61-80.

http://dx.doi.org/10.1002/smj.720

Mutinelli, M.; Piscitello, L. 1998. The entry mode choice of MNEs: an evolutionary approach, Research Policy 27: 491-506. http://dx.doi.org/10.1016/S0048-7333(98)00063-8

Newbert, S. L. 2007. Empirical research on the resource-based view of the firm: an assessment and suggestions for future research, Strategic Management Journal 28: 121-146.

http://dx.doi.org/10.1002/smj.573

Nielsen, R. P. 1988. Cooperative strategy, Strategic Management Journal 9(5): 475-492. http://dx.doi.org/10.1002/smj.4250090507

Nieto, M. J.; Fernández, Z. 2005. The role of information technology in corporate strategy of small and medium enterprises, Journal of International Entrepreneurship 3(4): 251-262.

http://dx.doi.org/10.1007/s10843-006-7854-z

O'Brien, R. M. 2007. A caution regarding rules of thumb for variance inflation factors, Quality and Quantity 41(5): 673-690. http://dx.doi.org/10.1007/s11135-006-9018-6

Osborne, K. 1996. The channel integration decision for small-to medium-sized manufacturing exporters, Journal of International Business Studies 14(3): 40-56.

http://dx.doi.org/10.1177/0266242696143002

Peng, M. W. 2001. The resource-based view and international business, Journal of Management 27: 803-829. http://dx.doi.org/10.1177/014920630102700611

Peng, M. W.; Ilinitch, A. Y. 1998. Export intermediary firms. a note on export development research, Journal of International Business 29(3): 609-620.

http://dx.doi.org/10.1057/palgrave.jibs. 8490010

Peng, M. W.; York, A. 2001. Behind intermediary performance in export trade: transactions, agents, and resources, Journal of International Business Studies 32(2): 327-346.

http://dx.doi.org/10.1057/palgrave.jibs.8490955

Plechero, M.; Chaminade, C. 2010. Different competences, different modes in the globalization of innovation? A comparative study of the Pune and Beijing regions, Circle working paper $3 / 2010$.

Rambocas, M.; Meneses, R.; Monteiro, C.; Brito, P. Q. 2015. Direct or indirect channel structures. Evaluating the impact of channel governance structure on export performance, International Business Review 24(1): 124-132. http://dx.doi.org/10.1016/j.ibusrev.2014.07.002

Reeb, D.; Sakakibara, M.; Mahmood, I. P. 2012. From the editors: endogeneity in international business research, Journal of International Business Studies 43(3): 211-218.

Reubert, A.; Fischer, E. The influence of the management teams international experience on the internationalization behaviors of SMEs, Journal of International Business Studies 28(4): 807-825. http://dx.doi.org/10.1057/palgrave.jibs.8490120

Rialp, A.; Axinn, C.; Thach, S. 2002. Exploring channel internalization among Spanish exporters, International Marketing Review 19: 133-165. http://dx.doi.org/10.1108/02651330210425006

Root, F. 1994. Entry strategies for international markets. Washington, DC: Lexington Books.

Sánchez-Peinado, E.; Pla-Barber, J. 2006. A multidimensional concept of uncertainty and its influence on the entry mode choice: an empirical analysis in the service sector, International Business Review 15(3): 215-132. http://dx.doi.org/10.1016/j.ibusrev.2006.02.002

Schwens, C.; Kabst, R. 2011. Entry learning, age at internationalization and foreign-venture performance of young technology firms, Technology Firms 63: 308-330. 
Sharma, V. M.; Erramilli, M. K. 2004. Resource-based explanation of entry mode choice, Journal of Marketing Theory and Practice 4: 1-18.

Shaver, J. M. 1998. Accounting for endogeneity when assessing strategy performance: does entry mode choice affect FDI survival?, Management Science 44: 571-585.

http://dx.doi.org/10.1287/mnsc.44.4.571

Shaver, J. M.; Flyer, F. 2000. Agglomeration economies, firm heterogeneity, and foreign direct investment in the United States, Strategic Management Journal 21: 1175-1193.

http://dx.doi.org/10.1002/1097-0266(200012)21:12<1175::AID-SMJ139>3.0.CO;2-Q

Sousa, C. M. P.; Martínez-López, F. J.; Coelho, F. 2008. The determinants of export performance: a review of the research in the literature between 1998 and 2005, International Journal of Management Reviews 10(4): 343-374. http://dx.doi.org/10.1111/j.1468-2370.2008.00232.x

Stiebale, J. 2010. The impact of foreign acquisitions on the acquirers' R\&D activities firm-level evidence, in The Summer Conference 2010, 16-18 June 2010, Imperial College London Business School.

Tabachnick, B. G.; Fidell, L. S. 2001. Using multivariate statistics. $4^{\text {th }}$ ed. Needham Heights, MA: Allyn \& Bacon.

Tallman, S.; Li, J. T. 1996. Effects of international diversity and product diversity on the performance of multinational firms, Academy of Management Journal 39(1): 179-96.

http://dx.doi.org/10.2307/256635

Tseng, C.-H.; Tansuhaj, P.; Hallagan, W.; McCullough, J. 2007. Effects of firm resources on growth in multinationality, Journal of International Business Studies 38: 961-974.

http://dx.doi.org/10.1057/palgrave.jibs.8400305

Vachani, S. 1995. Enhancing the obsolescing bargain theory: a longitudinal study of foreign ownership of US and European multinationals, Journal of International Business Studies 26(1): 159-180. http://dx.doi.org/10.1057/palgrave.jibs.8490170

Wilkinson, T.; Brothers, L. E. 2006. Trade promotion and SME export performance, International Business Review 15: 233-252. http://dx.doi.org/10.1016/j.ibusrev.2006.03.001

Wu, F.; Sinkovics, S.; Cavusgil, T.; Roath, A. S. 2007. Overcoming export manufacturers' dilemma in international expansion, Journal of International Business Studies 38: 283-302.

http://dx.doi.org/10.1057/palgrave.jibs. 8400263

Zahra, S. A.; Ireland, R. D.; Hitt, M. A. 2000. International expansion by new venture firms: International diversity, mode of market entry, technological learning, and performance, Academy of Management Journal 43(5): 925-50. http://dx.doi.org/10.2307/1556420

Marta FERNÁNDEZ-OLMOS obtained his PhD in 2008 (Extraordinary Award of doctoral thesis from University of Zaragoza) and is currently Associate Professor of Business Organization at the University of Zaragoza. Research interests are vertical relations and internationalization of small and medium enterprises. The author belongs to the Crevalor Research Group of the University of Zaragoza. She has published in Applied Economic Perspectives and Policy, Food Policy, British Food Journal, European Management Journal, among others. Research interests are vertical relations and exporting.

Isabel DÍEZ-VIAL is associate professor of Political Economy and Strategy in the Business Administration Department at the Universidad Complutense de Madrid. She has written about vertical boundaries, small and medium firm particularities in strategic decisions and clusters. She has published in Journal of Management Studies, Journal of Small Business Management, Growth and Change, Review of Industrial Organization, European Management Journal, among others. She belongs to a research group, supported with public funding, specialized in topics related to corporate strategy and clusters. 